\title{
Comparative analysis of the testes and spermatogenesis in species of the family Pentatomidae (Heteroptera)
}

\author{
Hederson Vinicius de SOUZA, Aline Sumitani MURAKami, Juliana de MOURA, Elisângela Cristiane \\ de ALMEIDA, Inaí́ Fernandes Gallego MARQUES and Mary Massumi ITOYAMA*
}

UNESP - Universidade Estadual Paulista, Instituto de Biociências, Letras e Ciências Exatas, Departamento de Biologia, Laboratório de Citogenética e Molecular de Insetos, São José do Rio Preto, São Paulo, Brasil; e-mail: mary@ibilce.unesp.br

Key words. Pentatomidae, harlequin lobe, meiosis, spermatogenesis, spermiogenesis

\begin{abstract}
There are few studies on the morphology and meiosis in the testicles of Heteroptera, but are extremely important, especially for the family Pentatomidae, because in some species in this family meiosis in the testicular lobes results in the production of non-fertile spermatozoa. With the aim of improving the level of understanding of this phenomenon the morphology of the testes and spermatogenesis in 10 species of Pentatomidae were recorded and compared. All of them have testes covered by a pigmented peritoneal sheath. In some species the internal membrane or just inside the peritoneal sheath is pigmented. The pigmentation of both membranes varied. The pigmentation of both was either yellow, or the internal membrane was yellowish and the external one reddish. When the membrane is pigmented, the colour is red or yellow. The number of lobes varied from 3 to 7 , with intermediate numbers of 4 and 6. The size and diameter of the lobes are similar in all the species studied, except Proxys albopunculatus, in which the diameter of the third and fifth is smaller than that of the other lobes. The behaviour of the cells during spermatogenesis was the same in all lobes of most species, except in P. albopunctulatus, in which the harlequin lobe is absent and the cells in lobes 4 and 6 exhibited characteristics different from those of cells in lobes 1-3 and 5. Chlorocoris complanatus and Loxa deducta (both Pentatominae) have a harlequin lobe (lobe 5). The chromosome complements recorded were: $2 \mathrm{n}=12(10 \mathrm{~A}+\mathrm{XY})$ in Dichelops melacanthus and Edessa collaris, $2 \mathrm{n}=14(12 \mathrm{~A}+\mathrm{XY})$ in C. complanatus, Edessa meditabunda, Ladeaschistus sp., Loxa deducta, P. albopunctulatus, Piezodorus guildinii and Thyanta perditor and $2 \mathrm{n}=16(14 \mathrm{~A}+\mathrm{XY})$ in Edessa affinis. Thus, this study extends the knowledge of characteristics, such as the pigmentation of the peritoneal sheath, number of testicular lobes, the occurrence of meiotic cells in some testicular lobes, and the chromosome complements of the family Pentatomidae.
\end{abstract}

\section{INTRODUCTION}

The Heteroptera, or true bugs, include 79 families, where the family Pentatomidae is one of the largest. They have a great diversity of habitats (parasites of birds and bats, live in spiders' webs and in water or on its surface), and they can be phytophagous (producing great damage to grain production), predators (providing great benefits, because they feed on phytophagous insects) or hematophagous (vector of Chagas disease to humans and rabies to bats) (Schuh \& Slater, 1995).

Heteroptera are characterized by possessing holokinetic chromosomes; moreover, the meiotic chromosomes lack kinetochore plates (Buck, 1967; Comings \& Okada, 1972; Motzko \& Ruthman, 1984; Rufas \& GiménezMartín, 1986; Wolf, 1996) and kinetic activity is restricted to the ends of the chromosomes (Schrader, 1935, 1940; Hughes-Schrader \& Schrader, 1961; Motzko \& Ruthmann, 1984; González-Garcia et al., 1996). Terminalization of chiasmata is presumed to occur (John \& King, 1985) although this is disputed (Jones, 1987; Solari \& Agopian, 1987) and the first meiotic division is reductional for autosomes and equational for sex chromosomes.

The sex chromosome systems of Heteroptera are: simple XY/XX (71.4\%) or X0/XX (14.7\%) and multiple (originating from the fragmentation of the $\mathrm{X}$ chromosome and less frequently, the $Y$ chromosome, $X_{n} 0 / X_{n} X_{n}$, $\mathrm{X}_{\mathrm{n}} \mathrm{Y} / \mathrm{X}_{\mathrm{n}} \mathrm{X}_{\mathrm{n}}$ and $\mathrm{XY} \mathrm{Y}_{\mathrm{n}} / \mathrm{XX}, 13.5 \%$ ) (Bressa et al., 2009). There is also a different system, termed neo-XY, reported in seven species and subspecies (0.4\%) (Papeschi \& Bressa, 2006).

The review of Papeschi \& Bressa (2006) records that over 1,600 species of Heteroptera, belonging to 46 families, have been cytogenetically analyzed. The diploid chromosome number varies from $2 \mathrm{n}=4$ (Lethocerus sp., Belostomatidae) to 80 (four species of Lopidae, Miridae) (Rebagliati et al., 2005; Papeschi \& Bressa, 2006). For the Pentatomoidea there is cytogenetic data for 391 species belonging to only nine families: Acanthosomatidae (12), Cydnidae (14), Dinidoridae (12), Plataspididae (16), Tessaratomidae (9), Thaumastellidae (2), Scutelleridae (27), Urostylididae (5) and Pentatomidae, with the last the most widely studied (294) (Rebagliati et al., 2005).

The family Pentatomidae, in terms of number of species, is one of the largest Heteropteran families, is cosmopolitan but more diverse in the tropics. It includes approximately 760 genera and 4,112 species (Schuh \& Slater, 1995; Schaefer \& Panizzi, 2000). These insects are known as "stink bugs" because they emit an unpleasant smell from glands that open in the metapleural region. Schuh \& Slater (1995) includes eight subfamilies in this

\footnotetext{
* Corresponding author.
} 
TABle 1. Testis characteristics of 10 species of the family Pentatomidae (Heteroptera) regarding the pigmentation of the testis membrane, number of testicular lobes and the presence or absence of harlequin lobe.

\begin{tabular}{lccc}
\hline Subfamily/ Species & Testis pigmented membrane & No. of lobes & Harlequin lobe \\
\hline $\begin{array}{l}\text { Pentatominae } \\
\text { Chlorochoris complanatus }\end{array}$ & Two membranes: yellowish internal and external & 7 & Yes (lobe 5) \\
$\begin{array}{l}\text { Dichelops melacanthus } \\
\text { Ladeaschistus } \text { sp. }\end{array}$ & One reddish membrane & 6 & No \\
Loxa deducta & One reddish membrane & 6 & No \\
Piezodorus guildinii & Two membranes: yellowish external and reddish internal & 6 & Yes (lobe 5) \\
Proxys albopunctulatus & One reddish membrane & 6 & Lobes 4 and 6 differentiated \\
Thyanta perditor & One yellowish membrane & 3 & No \\
Edessinae & & & No \\
Edessa affinis & Two membranes: yellowish external and reddish internal & 4 & No \\
Edessa collaris & One yellowish membrane & 4 & No \\
Edessa meditabunda & Two membranes: yellowish external and reddish internal & 4 & 7 \\
\hline
\end{tabular}

family: Asopinae, Cyrtocorinae, Discocephalinae, Edessinae, Pentatominae, Phyllocephalinae, Podopinae and Serbaninae. The most economically important are the phytophagous species of the subfamilies Edessinae and Pentatominae, which include most of the species that are grain pests. The species of Asopinae are predators and some important biological control agents (Schaefer \& Panizzi, 2000). The Pentatomidae have a diploid chromosome number of $2 \mathrm{n}=14$ and an $\mathrm{XY} / \mathrm{XX}$ sex chromosome system and no m-chromosomes (Schrader, 1945a, b; 1946a, b, 1960a, b; Ueshima, 1979; Manna, 1984; Rebagliati et al., 2005).

Some species of the family Pentatomidae, in addition to having a variable number of testicular lobes, may lack a distinctive lobe, called a harlequin lobe. Of the fifteen genera that have a harlequin lobe, eleven belong to the subfamily Discocephalinae, three to the Pentatominae and one to the Edessinae (Rebagliati et al., 2005). Therefore, of the eight subfamilies studied, only three (Discocephalinae, Edessinae, and Pentatominae) have this lobe.

In view of the above characteristics, i. e., the presence or absence of a harlequin lobe, variable number of chromosomes, different sex chromosome systems and few cytogenetic studies (meiotic behaviour), the purpose of this study was to generate knowledge with the objective of obtaining a better understanding of the biology of the Pentatomidae, by studying the pigmentation of the peritoneal sheath, number of lobes and the presence of a testicular harlequin lobe in the testes and the behaviour of cells during spermatogenesis.

\section{MATERIAL AND METHODS}

In the present study, 10 species of Heteroptera belonging to the family Pentatomidae were analyzed (subfamilies Pentatominae and Edessinae): Chlorocoris complanatus (Guérin, 1831) (Pentatominae), Dichelops melacanthus (Dallas, 1851) (Pentatominae), Edessa affinis (Dallas, 1851) (Edessinae), Edessa collaris (Dallas, 1851) (Edessinae), Edessa meditabunda (Fabricius, 1794) (Edessinae), Ladeaschistus sp. Rolston (Pentatominae), Loxa deducta (Walker, 1867) (Pentatominae), Piezodorus guildinii (Westwood, 1837) (Pentatominae), Proxys albopunctulatus (Palisot de Beauvois, 1805) (Pentatominae) and Thyanta perditor (Fabricius, 1794) (Pentatominae). A cytogenetic analysis of 10 adult males of each species collected at São José do Rio Preto $\left(20^{\circ} 47^{\prime} 32^{\prime \prime} \mathrm{S}, 4^{\circ} 21^{\prime} 37^{\prime \prime} \mathrm{W}\right)$, SP, Brazil, was carried out. The morphology, pigmentation of the peritoneal sheath and lobes of their testes were analyzed. The testicular lobes were separated, placed on histological slides and stained with lactic acetic orcein. The best images were captured with a Zeiss Axio A1 SCOPE microscope using the image analysis program Axio Vision LE version 4.8 (Carl Zeiss Jena, Germany).

\section{RESULTS}

\section{Testes}

All species of the Pentatomidae (Chlorocoris complanatus, Dichelops melacanthus, Edessa affinis, Edessa collaris, Edessa meditabunda, Ladeaschistus sp., Loxa deducta, Piezodorus guildinii, Proxys albopunctulatus and Thyanta perditor) analyzed have elongated testes (Fig. 1). In all these species, the testes were covered by a pigmented peritoneal sheath and in some species the internal membrane of the peritoneal sheath (C. complanatus, E. affinis, E. meditabunda, Loxa deducta and Piezodorus guildinii) (Fig. 1a-d) or only the peritoneal sheath (D. melacanthus, E. affinis, E. meditabunda, Ladeaschistus sp., Proxys albopunctulatus and T. perditor), was pigmented (Fig. 1e, f). The pigmentation of both membranes also varied. Both could be yellowish (C. complanatus and Loxa deducta) (Fig. 1c, d) or the internal reddish and the external membrane yellowish (E. affinis, E. meditabunda and Piezodorus guildinii) (Fig. 1a, b). When there was only one membrane, the pigmentation was: reddish (D. melacanthus, Ladeaschistus sp. and Proxys albopunctulatus) (Fig. 1e) or yellowish (E. collaris and T. perditor) (Fig. 1f) (Table 1). The number of lobes varied from three ( $T$. perditor) to seven $(C$. complanatus and Loxa deducta), with intermediate numbers of four ( $E$. affinis, E. collaris and E. meditabunda) and six (Ladeaschistus sp., D. melacanthus, Piezodorus guildinii and Proxys albopunctulatus) (Fig. 2a-f). The diameters of the lobes were generally similar, except in Proxys albopunculatus, in which the diameters of the third and fifth was narrower than those of the other lobes (Fig. 2f).

\section{Cell behaviour in the testicular lobes}

The analysis of the presence or absence of cells with different characteristics in the testicular lobes indicates that in Dichelops melacanthus (Pentatominae), Edessa 

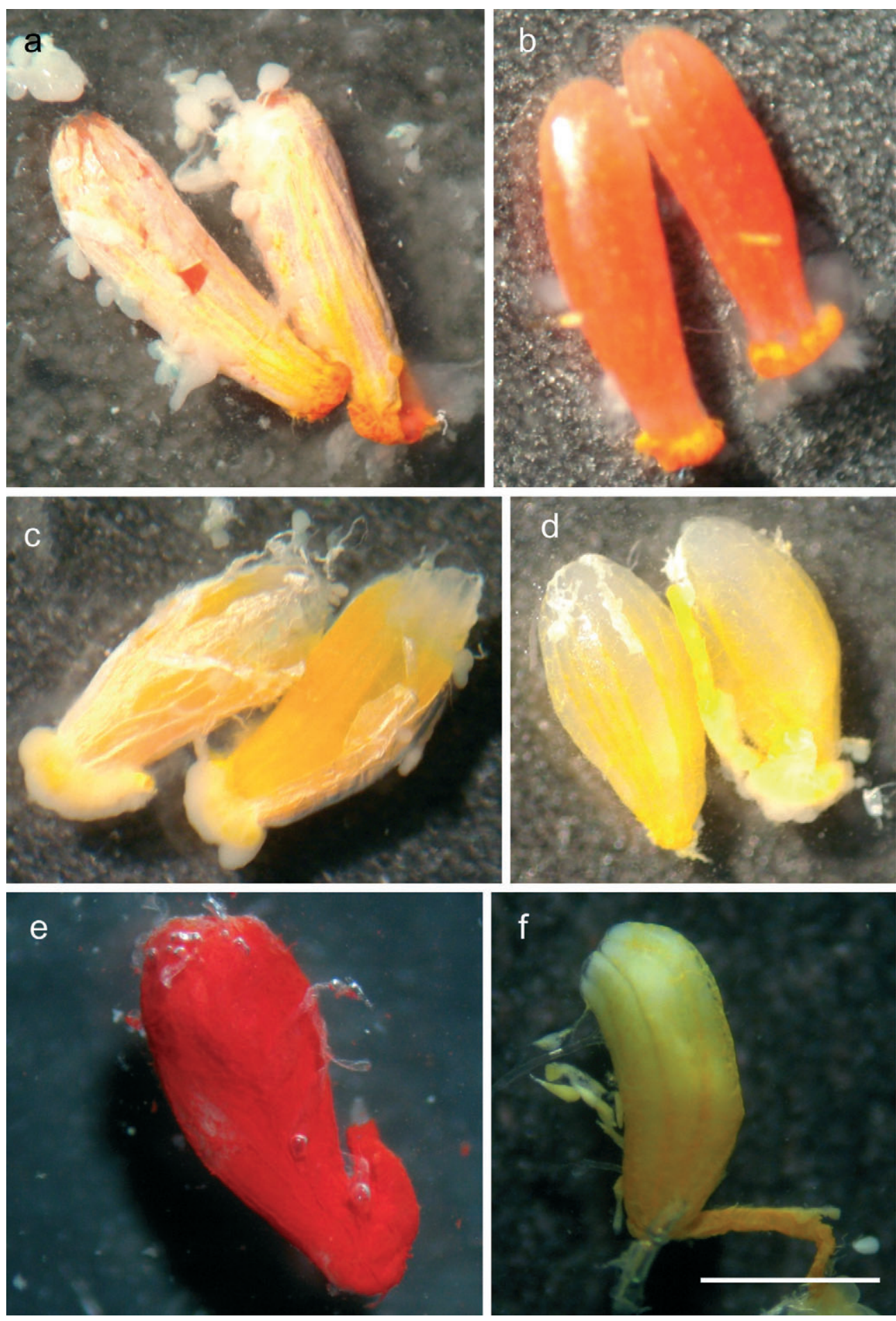

Fig. 1. Testes of Edessa affinis (a, b), Loxa deducta (c, d), Ladeaschistus sp. (e) and Edessa collaris (f). Note the presence of two $(a, c)$ yellowish membranes surrounding the testicles, (a) an internal reddish membrane (b, testis without peritoneal sheath) or both are yellowish (c). Note in (d) testicle without an external membrane; e, f-presence of only one pigmented peritoneal sheath, which may be reddish (e) or yellow (f). Bar $=1 \mathrm{~mm}$.

affinis (Edessinae), Edessa collaris (Edessinae), Edessa meditabunda (Edessinae), Ladeaschistus sp. (Pentatominae), Piezodorus guildinii (Pentatominae) and Thyanta perditor (Pentatominae) the cells in all lobes behaved similarly during spermatogenesis. Proxys albopunctulatus (Pentatominae) does not have a harlequin lobe, but the cells in lobes 4 and 6 differed in their behaviour from those in lobes 1-3 and 5. Chlorocoris compla- natus (Pentatominae) and Loxa deducta (Pentatominae) have a harlequin lobe (lobe 5). Therefore, there are three different groups of testicular lobes: Group 1 includes all lobes of seven species the cells of the testicular lobes of which do not differ, lobes 1-3 and 5 of Proxys albopunctulatus and lobes $1-4$ and 6 and 7 of $C$. complanatus and Loxa deducta; Group 2 includes lobes 4 and 6 of Proxys albopunctulatus, which do not have a harlequin lobe but 

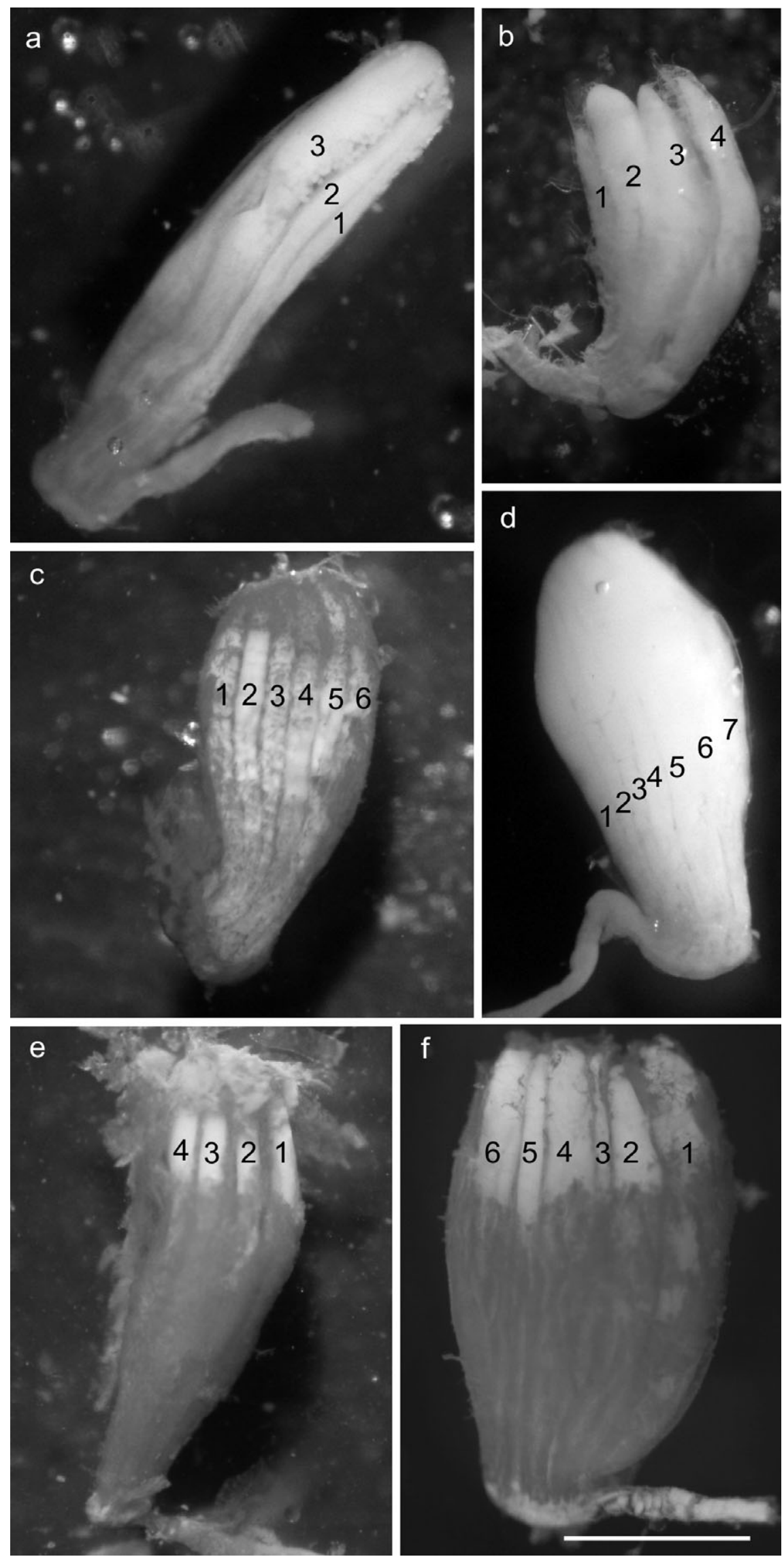

Fig. 2. Testes of Edessa collaris (b), Edessa meditabunda (e), Ladeaschistus sp. (c), Loxa deducta (d), Proxys albopunctulatus (f) and Thyanta perditor (a) with the testicular lobes numbered. The numbers of lobes recorded were 3, 4, 6 and 7 (a, b, c, d, respectively). Lobes may be the same diameter (e) or different diameters as in P. albopunctulatus (lobes 3 and 5, minor) (f). Bar $=1 \mathrm{~mm}$. 

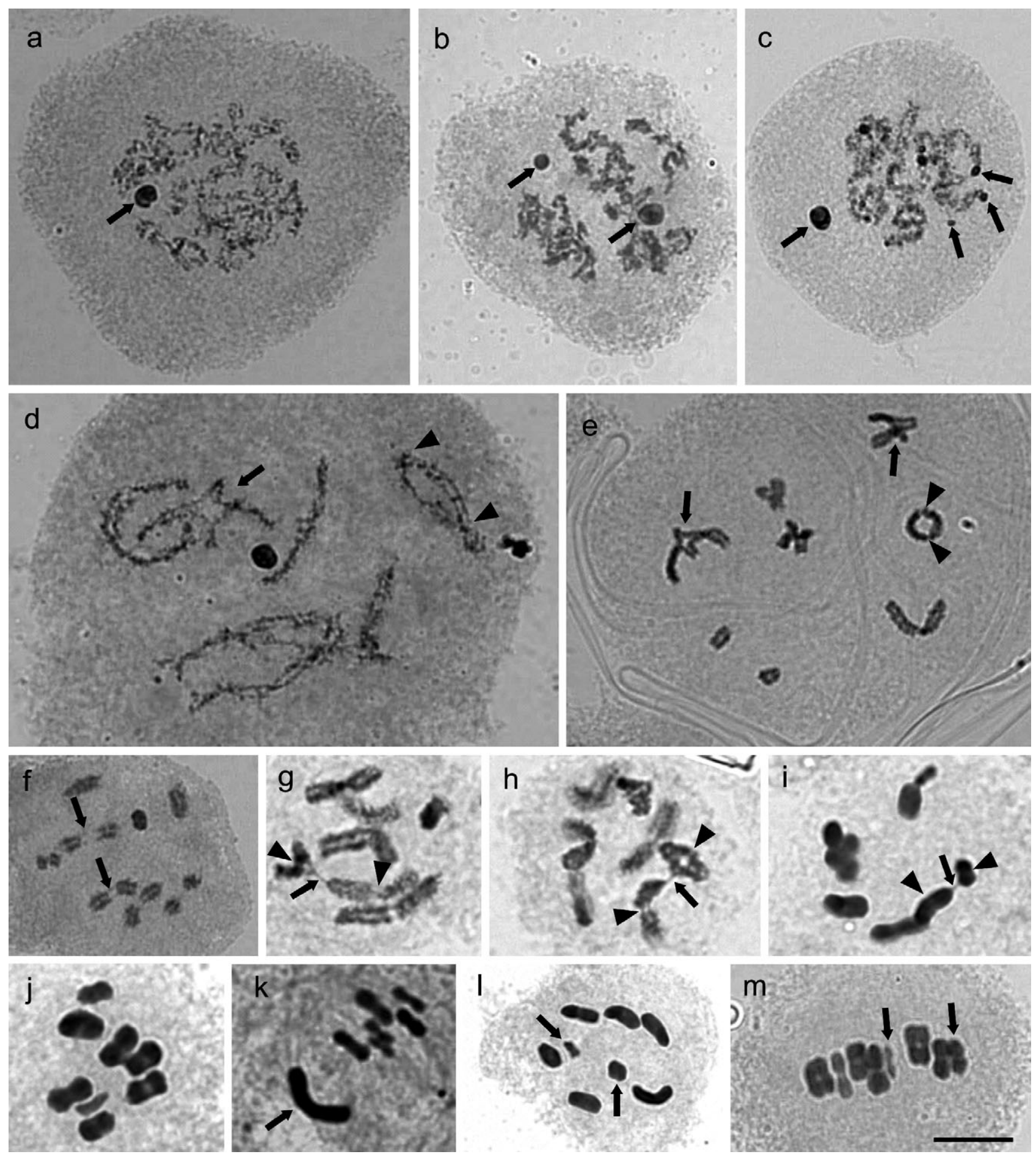

Fig. 3. Cells of the testicular lobes of Chlorocoris complanatus (d), Dichelops melacanthus (k), Edessa affinis (c), Edessa meditabunda (b, m), Loxa deducta (a, e), Piezodorus guildinii (g, h, i, j, l) and Thyanta perditor (f) of group 1 stained with lactic acetic orcein. a-c-Meiotic prophase I with one (a) or two (b) heteropycnotic bodies or one large and several small heteropycnotic corpuscles (c) (arrows); d, e - diplotene and diakinesis, respectively, showing interstitial (arrows) and terminal chiasmata (arrowheads); $\mathrm{f}$ - late prophase I with chromatin filaments joining the homologous chromosomes (arrows); $\mathrm{g}-\mathrm{i}$ - late prophase I bivalents (arrowheads indicate chiasmata, arrows chromatin filaments connecting some bivalents); $\mathrm{j}, \mathrm{k}$ - metaphase I showing autosomes of similar size (j), except in D. melacanthus, where one of the autosomes is considerably larger than the other (k, arrow); $1-$ metaphase $\mathrm{I}$ in polar view, with a ring of autosomes with the sex chromosomes at its center; $\mathrm{m}$ - metaphase I in lateral view. Arrows indicate the sex chromosomes in (l) and (m). Bar: $10 \mu \mathrm{m}$.

the cells in these lobes behave differently from those in other lobes; and Group 3 includes description of the harlequin lobe (lobe 5) of C. complanatus and Loxa deducta.

\section{Meiotic behaviour of cells in Group 1}

All cells at meiotic prophase $\mathrm{I}$, in this group, had a rounded heteropycnotic body (Fig. 3a) or two, one larger 

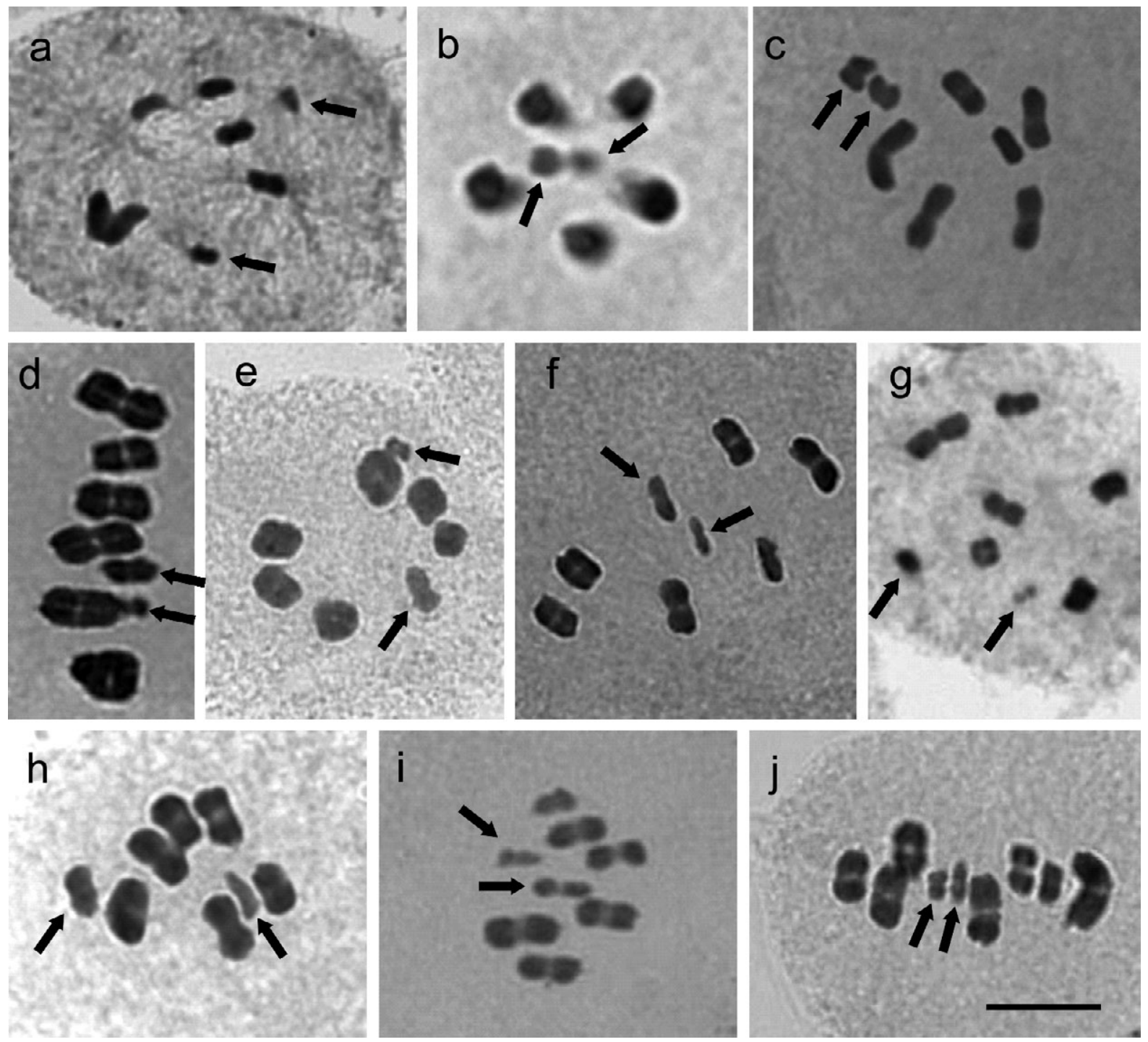

Fig. 4. Metaphases I showing chromosome complements of $2 \mathrm{n}=12(10 \mathrm{~A}+\mathrm{XY})$ in D. melacanthus and E. collaris $(\mathrm{a}, \mathrm{b}$ respectively), 2n = $14(12 \mathrm{~A}+\mathrm{XY})$ in C. complanatus, E. meditabunda, Ladeaschistus sp., Loxa deducta, P. albopunctulatus, $P$. guildinii and T. perditor (c-i, respectively), and $2 \mathrm{n}=16(14 \mathrm{~A}+\mathrm{XY})$ in E. affinis (j). Arrows indicate the sex chromosomes. Bar: $10 \mu \mathrm{m}$.

than the other (Fig. 3b). These heteropycnotic bodies possibly consist of the $\mathrm{X}$ and $\mathrm{Y}$ chromosomes, which occur together or separate. In addition to the sex chromosomes, regions of autosomes could also be heteropycnotic, with several minor intense staining bodies or one major and several minor (Fig. 3c). All these heteropycnotic bodies persisted until the end of prophase I. Another characteristic observed in all these species is the presence of chiasmata, which are either interstitial (Fig. 3d-f) or terminal (Fig. 3f).

All homologous chromosomes were associated with the telomeric regions, and in some species there were chromatin filaments connecting different bivalents (Fig. 3g). Piezodorus guildinii besides showing telomeric associations between homologous chromosomes, showed associations between different bivalents, which were observed up to the end of prophase I (Fig. 3h-j). The autosomes were similar in size (Fig. 3j), except in Dichelops melacanthus, where one of the autosomes was considerably longer than the others (Fig. 3k), a feature easily observ- able at metaphase I, when the chromosomes were most condensed. During metaphase I, the autosomes formed a ring with the sex chromosomes at the center (polar view, Fig. 31). The chromosomes could also be observed distributed linearly on the equatorial plate of the cell (side view, Fig. $3 \mathrm{~m}$ ).

The chromosome complements were: $2 \mathrm{n}=12(10 \mathrm{~A}+$ $\mathrm{XY}$ ) in D. melacanthus and E. collaris (Fig. 4a, b, respectively), $2 \mathrm{n}=14(12 \mathrm{~A}+\mathrm{XY})$ in $C$. complanatus, $E$. meditabunda, Ladeaschistus sp., Loxa deducta, Proxys albopunctulatus, Piezodorus guildinii and T. perditor (Fig. 4c-i, respectively), and $2 \mathrm{n}=16(14 \mathrm{~A}+\mathrm{XY})$ in $E$. affinis (Fig. 4j).

At anaphase I, a regular migration of all the chromosomes was observed (Fig. 5a). At metaphase II, the autosomes were arranged in a fashion similar to that at metaphase I, i.e., with the autosomes forming a ring and sex chromosomes in the center (Fig. 5b-f). At this stage, the sex chromosomes $\mathrm{X}$ and $\mathrm{Y}$ form a pseudo-bivalent (Fig. 5c). It was noted that the sex chromosomes at the 

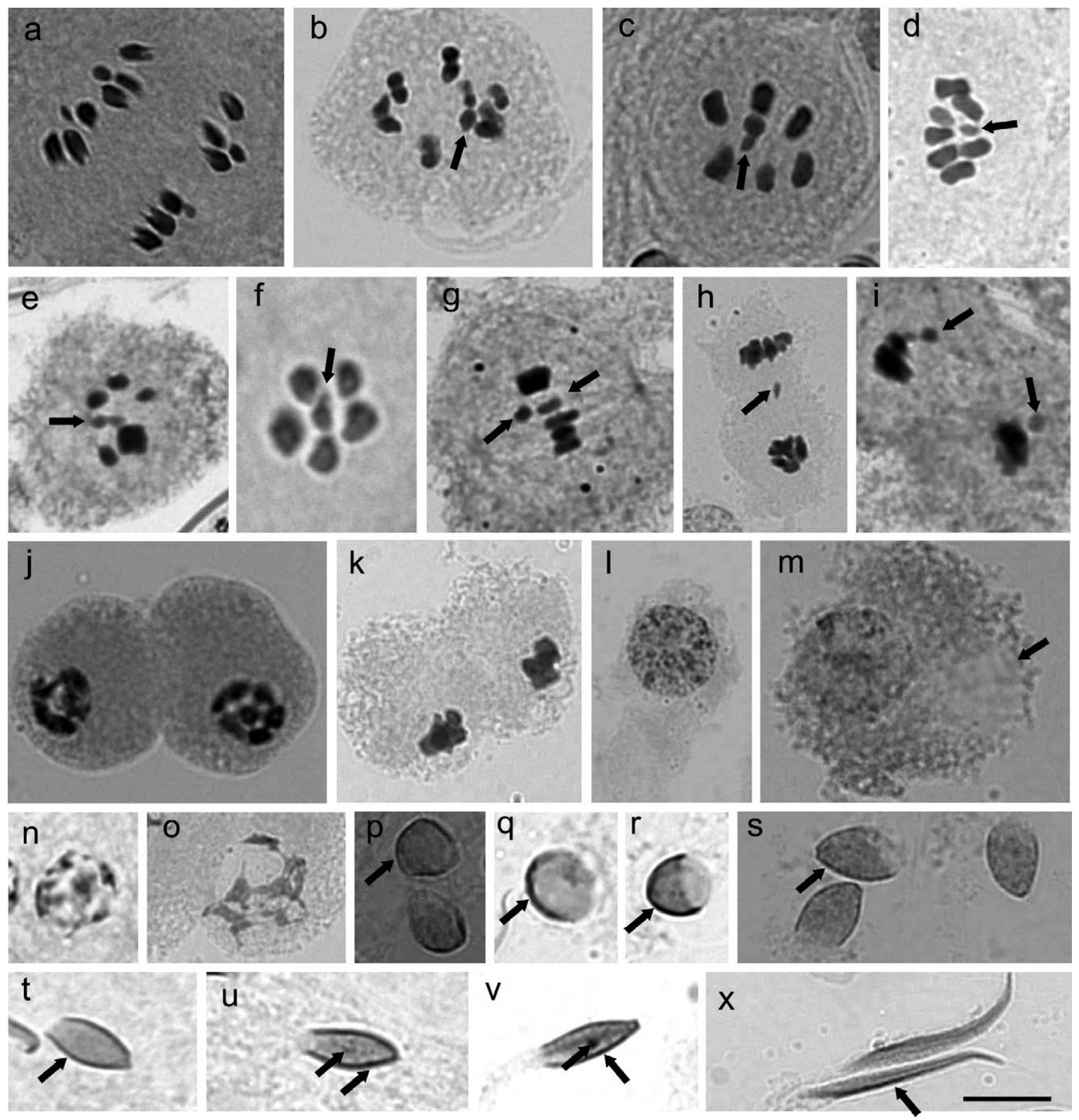

Fig. 5. Cells of the testicular lobes of Chlorocoris complanatus (m), Dichelops melacanthus (e, g, i), Edessa affinis (b, p), Edessa collaris (f), Edessa meditabunda (c, j, k, o, x), Loxa deducta (a, 1, s), Piezodorus guildinii (d, n, q, r, t, u, v), and Thyanta perditor (h) of group 1 stained with lactic acetic orcein. $\mathrm{a}$ - anaphase I; $\mathrm{b}-\mathrm{f}$ - metaphase II (arrows indicate the pseudobivalent); $\mathrm{g}-$ anaphase II (arrows indicate the sex chromosome $\mathrm{Y}$, left, and $\mathrm{X}$, right); $\mathrm{h}$ - anaphase II with late migration of the X chromosome (arrow); $\mathrm{i}-$ anaphase II (arrows indicate the sex chromosomes); $\mathrm{j}, \mathrm{k}$ - telophase II at different stages; 1 - round spermatid, with several heteropycnotic corpuscles; $\mathrm{m}$ - round spermatid with a large vesicle (arrow); $\mathrm{n}$ - round spermatid with chromatin located in some regions of the nucleus; o - spermatid with a vesicle inside; $p-r$ - spermatids with heteropycnotic material located in the nuclear envelope (arrows); s, t - elliptic spermatids, with chromatin material around the nuclei (arrows); $\mathrm{u}, \mathrm{v}$ - spermatids with heteropycnotic material around the nuclei and in the center of the spermatid (arrows); $\mathrm{x}-$ spermatid elongating. The arrow indicates heteropycnotic material. Bar: $10 \mu \mathrm{m}$.

first division, migrate equationally (Fig. 5a, each cell receives one chromatid of chromosomes $\mathrm{X}$ and $\mathrm{Y}$ ) and that the second division is reductional (Fig. $5 \mathrm{~g}$ ).

At the beginning of anaphase II, it was possible to verify the sex chromosomes, $\mathrm{X}$ and $\mathrm{Y}$, separate (Fig. 5g). Sometimes, it was observed that the sex chromosome lagged behind the other chromosomes during migration at this phase (Fig. 5h). At the end of anaphase II, the sex chromosome separated from the autosomes (Fig. 5i). At telophase II, the chromosomes were associated with the telomeric region, forming a ring (Fig. 5j), and at a later stage, the chromosomes were scattered (Fig. 5k). 

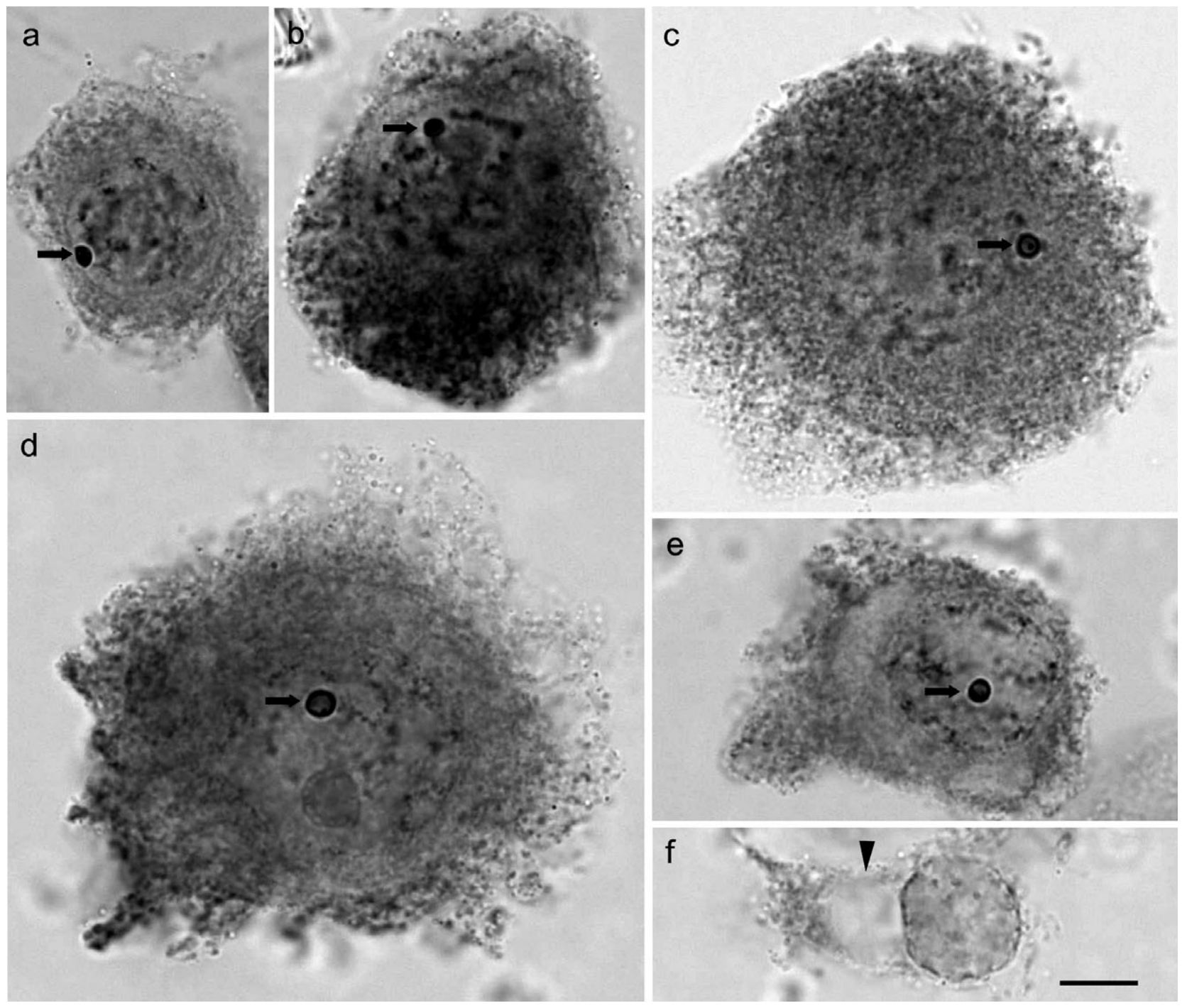

Fig. 6. Cells of the testicular lobes in group 2 (lobes 4 and 6 of Proxys albopunctulatus, Pentatomidae) stained with lactic acetic orcein. a-c - Cells at prophase I of different sizes with a strongly stained heteropycnotic corpuscle (arrows); d, e - Cell at prophase I with cytoplasmic projection over the entire cell. The arrow indicates the heteropycnotic corpuscle; $\mathrm{f}-$ spermatid with a large vesicle (arrowhead). Bar: $10 \mu \mathrm{m}$.

In early spermiogenesis, the spermatids had round nuclei (Fig. 51), and in some species (Chlorocoris complanatus) had a vesicle similar in size to the nucleus (Fig. $5 \mathrm{~m})$. The chromatin of the spermatids could be distributed throughout the cell, with some heteropycnotic bodies (Fig. 5n) or located in particular regions of the nucleus (Fig. 5o). Only in Edessa meditabunda was the chromatin associated with a vesicle (Fig. 5o). In subsequent phases, most of the chromatin was in the nuclear envelope of the round spermatids (Fig. 5p) and latter in development in only three quarters of the nuclei (Fig. 5q, r). In the next stage, the spermatids were elliptical and the chromatin associated with them was more intense around the nucleus (Fig. $5 \mathrm{~s}, \mathrm{t}$ ). In the elongating elliptical spermatids, the chromatin was also in the central region of the spermatid (Fig. $5 \mathrm{u}, \mathrm{v}$ ). In elongated spermatids, the chromatin was more strongly stained on only one side (Fig. 5x).

\section{Meiotic behaviour of cells in Group 2}

In lobes 4 and 6 of Proxys albopunctulatus, cells at prophase were of different sizes, with a rounded, intensely stained heteropycnotic body (Fig. 6a-c). Over the entire surface of the largest cells at prophase I there were some cytoplasmic projections (Fig. 6d), in addition to the heteropycnotic body. In a subsequent phase, the projections decreased in size, probably due to the loss of cytoplasm (Fig. 6e). Another feature of these lobes was the presence of spermatids with a large vesicle on the posterior region of the head (Fig. 6f). Other stages of spermatogenesis were the same as in the Group 1.

\section{Meiotic behaviour of cells in Group 3}

The prophase cells in lobe 5 in Chlorocoris complanatus and Loxa deducta were polyploid and had a large heteropycnotic body and several smaller bodies (Fig. 7a). At this stage, the cells usually exhibited scattered chromatin and several heteropycnotic regions that varied from cell to cell and were larger than in the cells of Group 1, at 

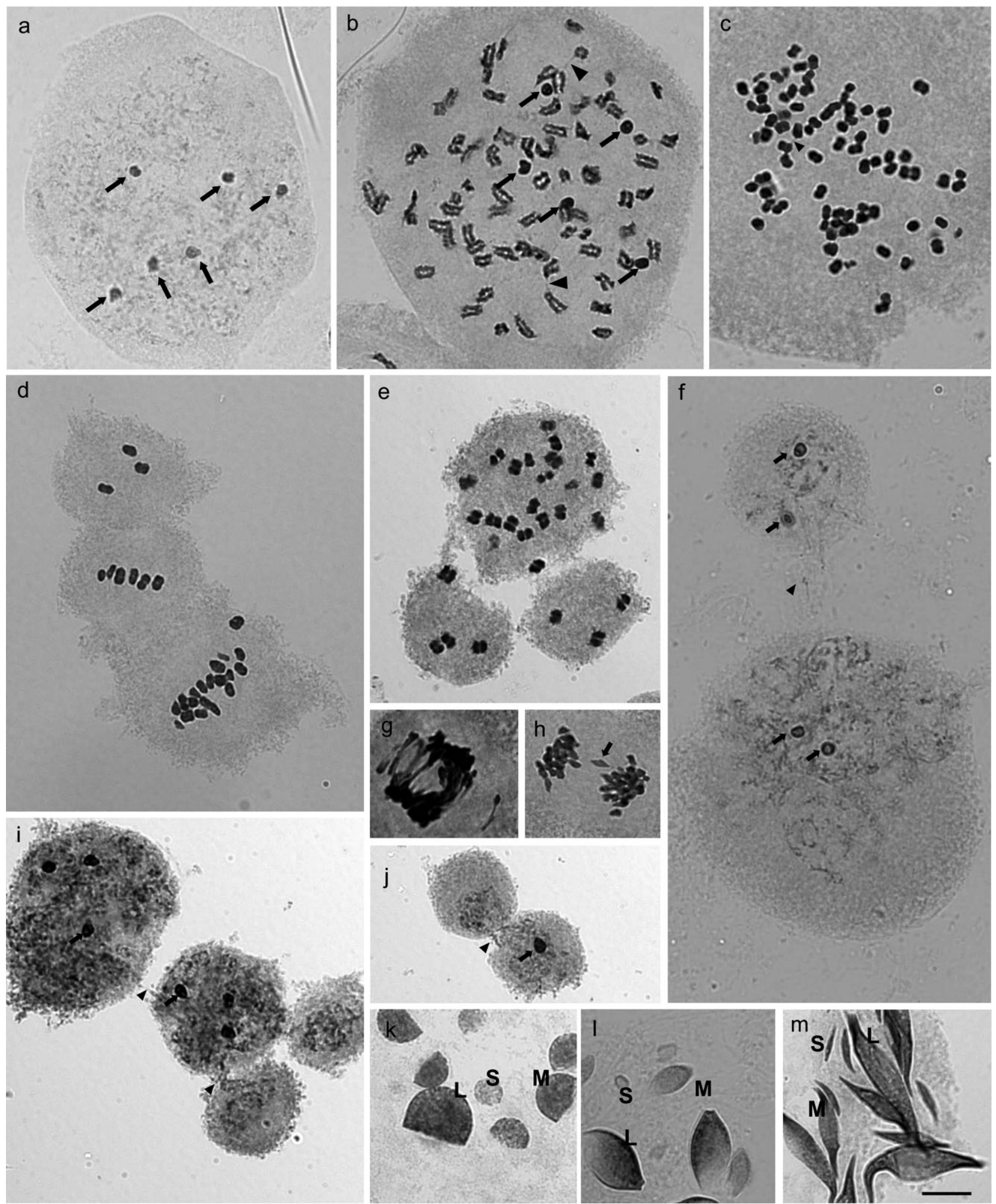

Fig. 7. Cells of the testicular lobes of group 3 (lobe 5 of Chlorocoris complanatus (f, l) and Loxa deducta (a, c, d, e, g, h, i, j, k, l) (Pentatomidae) stained with lactic acetic orcein. a - cell in prophase I containing several rounded heteropycnotic corpuscles (arrows); b, c-metaphase I cell showing several condensed chromosomes and several rounded heteropycnotic corpuscles (arrows) and some chromosomes showing chromatin filaments (arrowhead); $\mathrm{d}$, e - anaphase I showing different ways of dividing; $\mathrm{f}$ - nuclei after meiosis I showing unequal distribution of chromatin material. Note heteropycnotic regions (arrows) and chromatin material between two cells (arrowhead); $\mathrm{g}$ - early anaphase II; $\mathrm{h}$ - anaphase II with late migration of chromosome (arrow); $\mathrm{i}$ - nuclei after meiosis II showing several heteropycnotic corpuscles (arrows) and unequal distribution of genetic material between cells (arrowhead). Note chromatin material between cells (arrowhead); $\mathrm{j}$ - nuclei after meiosis II showing separation of genetic material and only one heteropycnotic corpuscle (arrow). Note genetic material at the site of separation of cells (arrowhead); $\mathrm{k}-\mathrm{round}$ spermatids of different sizes: small (S), medium (M) and large (L); 1, m - spermatids of different sizes elongating: small (S), medium (M) and large (L). Bar: $10 \mu \mathrm{m}$. 
the same phase (Fig. 7a). In this lobe, the intermediate phases of the process of condensation of chromosomes and the formation of chiasmata were not observed. The second stage of meiotic metaphase occurred at different degrees of chromatin condensation (Fig. 7b, c). Another feature was the large number of chromosomes and heteropycnotic regions, which varied in number from cell to cell (Fig. 7b, c).

At anaphase I different characteristics and features were observed and are described below: (i) the chromosomes were highly condensed, with a well-defined morphology (Fig. 7d, e), or scattered; however, the heteropycnotic bodies were clearly visible (Fig. 7f, j); (ii) the number of cells formed varied from two (Fig. 7f) to four (Fig. 7i), (iii) the manner in which the cells separated also differed, when a single cell was formed from one of three in a sequence (Fig. 7d) or three interconnected cells (Fig. 7e), (iv) another feature is that there was always chromatin in the region of separation between the cells (Fig. 7e, $\mathrm{f}, \mathrm{i}, \mathrm{j}$ ).

It was also clear that the amount of genetic material each cell receives differed and this is independent of whether the chromosomes are condensed (Fig. 7d, e) or scattered (Fig. 7f, j). When the chromosomes were scattered, some cells did not receive any heteropycnotic material (Fig. 7i, j). Anaphase, in lobe 5, was of "traditional" form, with the chromosomes/chromatids separating on the equatorial plate of the cell (Fig. $7 \mathrm{~g}, \mathrm{~h}$ ), and a late migration of chromosomes (Fig. 7h).

Spermiogenesis begins with round spermatids of three different sizes: small (S), medium (M) and large (L) (Fig. $7 \mathrm{k})$. In these cells the chromatin was not distributed throughout the cell and was restricted to approximately $50 \%$ of the cell. There are also three sizes of elongating spermatids in which chromatin was also not equally distributed throughout the cell, but more concentrated in the anterior region of the head (Fig. 71). This distribution persisted in the elongated spermatids (Fig. $7 \mathrm{~m}$ ).

\section{DISCUSSION}

One characteristic still very little explored in Heteroptera is the pigmentation of the peritoneal sheath that surrounds the testes. The species of the Pentatomidae analyzed in this study had two membranes of the same colour (yellow) or different colours (external yellow and internal reddish) or a single membrane (yellow or red). In these species, there is no relationship between the colour of the membrane and, for example, the subfamily or number of testicular lobes. Other species described in the literature have a reddish sheath, for example, Hyalymenus sp. and Neomegalotomus pallescens (Alydidae, Souza et al., 2009), Anasa bellator, Athaumastus haematicus, Catorhintha guttula, Dallacoris obscura, Dallacoris pictus, Hypsilonotus fulvus, Leptoglossus gonagra, Leptoglossus zonatus and Sphictyrtus fasciatus (Coreidae) (Souza et al., 2007a, 2009), Nysius californicus (Lygaeidae) (Souza et al., 2007b), Antiteuchus tripterus, Mormidae v-luteum, Oebalus poecilus and Oebalus ypsilogriseus (Pentatomidae) (Souza et al., 2007c, 2008) and
Niesthrea sidae (Rhopalidae) (Souza et al., 2009), or yellow as in Zicca annulata (Souza et al., 2007a) or colourless as in Chariesterus armatus (Coreidae, Souza et al., 2007a) and Limnogonus aduncus (Gerridae, Castanhole et al., 2008). Comparison of the results presented here and the little data on this topic in the literature indicates that there is no pattern in the colour of the sheath, in terms of the family to which the species belong, because, for example, in the family Coreidae, the peritoneal sheath is reddish, yellowish or is not pigmented. Although there is no pattern, reddish colour is prevalent.

One of the common features of all Heteroptera is that they have testes formed of lobes, which are elongated and usually arranged side by side. They also have a variable number, for example, in the Coreidae it varies from three to seven (Souza et al., 2007a). According to the literature, the number of lobes in the family Lygaeidae is variable, with species with two, four, six and seven lobes, where seven is considered the ancestral number (Grozeva \& Kuznetsova, 1992). According to the literature, Limnogonus aduncus (Gerridae, Castanhole et al., 2008) has two testicular lobes, Mormidae v-luteum (Pentatomidade, Souza et al., 2008) three lobes, Oebalus poecilus, Oebalus ypisilongriseus (Pentatomidae, Souza et al., 2008), Zicca annulata and Chariesterus armatus (Coreidae, Souza et al., 2007a) four lobes, Antitheuchus tripterus (Pentatomidae, Souza et al., 2007c) six lobes, Nysius californicus (Lygaeidae, Souza et al., 2007b), Anasa bellator, Athaumastus haematicus, Dallacoris obscura, Dallacoris pictus, Leptoglossus gonagra, Leptoglossus zonatus and Sphictyrtus fasciatus (Coreidae, Souza et al., 2007a) seven lobes. Based on a literature review, the family Pentatomidae (Souza \& Itoyama, 2010) includes six species of the subfamily Asopinae, in which only one species (Euthyrhynchus floridanus) has six testicular lobes and the others seven. In the other subfamilies, the distribution of lobes differs, ranging from four to eight in the Discocephalinae, four to five in the Edessinae and three to seven in the Pentatominae. The species of the Pentatomidae analyzed in this study also had different numbers of lobes (3-7). Only the three species belonging to genus Edessa have the same number of testicular lobes (4). Thus, in terms of the number of lobes, there is no indication of what is the ancestral number of lobes, or if this feature is related or not to the family, since the number of species analyzed is still too small. Therefore, there is a need for a larger number of species and families to be analyzed.

Another feature recorded in only some species of the family Pentatomidae is the presence of a lobe that differs from the others, called a harlequin lobe. The subfamilies that often have such a lobe are the Edessinae, Pentatominae and Discocephalinae (Rebagliati et al., 2005). All species examined in this study belong to these subfamilies, but only C. complanatus and Loxa deducta, both in Pentatominae, have such a lobe. One characteristic these two species have in common is the total number of lobes (7) the fifth of which is a harlequin lobe. 
According to Schrader (1945a, b; 1946a, b), the occurrence of the harlequin lobe is neither accidental nor sporadic. This lobe is present in both testes of all males of a species and is always the same lobe. In the Discocephalinae, for example, the harlequin is usually lobe 5, numbered from the ejaculatory duct. In most cases, when lobes 4 and 6 show polymegaly, lobe 5 shows atypical meiosis, with the only exception being Euschistus heros (Pentatomidae: Carpocorini), which in addition to lacking a harlequin lobe, has a very narrow fifth lobe (Souza \& Itoyama, 2010). The present study found that Proxys albopunctulatus (Pentatomidae: Carpocorini) belongs this select group, i.e., it lacks a harlequin lobe, and lobe 5 is flanked by lobes that produce differentiated cells and has a small diameter. Other species of the genus Euschistus have a harlequin lobe (Bowen, 1922). Thus, P. albopunctulatus displays testicular characteristics more closely related to those of $E$. heros than other species of the genus Euschistus. The capacity of sperm of different morphologies to fertilize has not been demonstrated. At least in the case of large sperm, a nutrition role similar to that proposed for harlequin sperm (Schrader, 1960a) could be one advantage of producing sperm of different morphologies. Other techniques should be used to clarify the evolution and/or biological function of the lobes that produce non-fertile sperm.

Another characteristic of the species that have a harlequin lobe is that the behaviour of cells differs mainly during metaphase and anaphase. In these phases, the chromosomes are either condensed or scattered, such as in the species analyzed in this study, or scattered as seen in Antiteuchus tripterus (Souza et al., 2007c).

The Heteroptera, besides being diverse and comprising one of the major suborders, also have holokinetic chromosomes (Ueshima, 1979; Souza et al., 2007a; Castanhole et al., 2008; Costa et al., 2008). At leptotenezygotene, the $\mathrm{X}$ chromosome is positively heteropycnotic and is located on the periphery of the nucleus and at zygotene and pachytene, the chromosomes are tangled. At the end of diakinesis, the $\mathrm{X}$ chromosome becomes isopycnotic (Bressa et al., 2002). The species analyzed in this study also showed these characteristics, indicating that they are standard for Heteroptera. However, according to the literature, the sex chromosome is not always the one that appears heteropycnotic, as in Belostoma dentatum the autosomal bivalents are continuously condensed, with both sex chromosomes scattered and negatively heteropycnotic during diakinesis (Papeschi \& Bidau, 1985).

In the suborder Heteroptera, the bivalents usually have a terminal chiasma (Ueshima, 1979; Manna, 1984). During prophase I, interstitial or terminal chiasmata are also observed, single or double. The chiasmata in the species analyzed in this study did not have a specific morphology, as in species of the Coreidae with the interstitial chiasmata in cross form (Souza et al., 2007a). However, more detailed studies of the morphology and frequency of chiasmata are needed.

At metaphase I, the X chromosome is located in the center of the ring formed by the autosomal bivalents. At anaphase I the autosomal bivalents divide reductionally, while the $\mathrm{X}$ chromosome divides equationally, with late migration of the sex chromosome sometimes observed. The second division follows directly after telophase I, with no interkinesis. At metaphase II, the autosomes lie in the equatorial plane forming a ring configuration, with the $X$ chromosome in its center (Bressa et al., 2002). After telophase II, the daughter cells begin the process of spermiogenesis, by differentiation of spermatocytes and elongation of these cells. These characteristics also are the same as those found in the species analyzed in this study, showing that it is the pattern for species of Heteroptera, which have a XY sex chromosome determination system. Regarding the number of autosomes in Heteroptera, they vary from $2 \mathrm{n}=4$ (Belostomatidae) to 80 (Miridae), but these numbers are not typical of the suborder (Ueshima, 1979). It is difficult to establish the modal chromosome number for the entire suborder, because the eight infraorders in the Heteroptera are not studied cytologically to the same extent (Grozeva \& Nokkala, 1996).

Within the family Pentatomidae, 303 species and subspecies belonging to 126 genera have been cytogenetically analyzed. The male diploid numbers are between 6 and 27 with a modal number of 14 chromosomes, which is present in $85 \%$ of the species. Pentatomids lack $\mathrm{m}$-chromosomes, and their sex chromosome system is $\mathrm{XY}$ / XX, except for only three species: Macropygium reticulare (Fabricius) $\left(\mathrm{X}_{1} \mathrm{X}_{2} \mathrm{Y}\right), \quad$ Rhytidolomia senilis (neo-X/neo-Y) and Thyanta calceata (Say) $\left(\mathrm{X}_{1} \mathrm{X}_{2} \mathrm{Y}\right)$ (Schrader, 1946a, b, 1960a, b; Rebagliati et al., 2005; Souza et al., 2007a). Chlorocoris complanatus, Edessa meditabunda, Ladeaschistus sp., Loxa deducta, Proxys albopunctulatus, Piezodorus guildinii and Thyanta perditor analyzed in this study have the sex chromosome system XY/XX (male / female). These species also have the same chromosome complement of $2 n=14$ chromosomes $(70 \%$ of analyzed species), except $D$. melacanthus, $E$. collaris, which has $2 \mathrm{n}=12$ chromosomes and $E$. affinis with $2 \mathrm{n}=16$ chromosomes. This family is cytogenetically highly homogeneous and karyotype changes probably played a minor role in its speciation. The diploid numbers of 12,14 , and 16 chromosomes are present in approximately $95 \%$ of the species of Pentatomidae (Papeschi \& Bressa, 2006; Rebagliati \& Mola, 2010). It is interesting to note that the three species of the genus Edessa have different chromosome complements, suggesting a chromosomal rearrangement has occurred in this genus.

The origin of the chromosome complement, which consists of a high number of chromosomes derived from a smaller number by fission of a pair of autosomes, is discussed in the literature (Ueshima \& Ashlock, 1980). According to Jacobs (2004), because Heteroptera have holokinetic chromosomes, fragmentation is the most likely, because it generates segments that may migrate regularly to the poles during anaphase and survive for many cell generations. Likewise, chromosomal fusion is also theoretically more likely in organisms with holokinetic chromosomes. 
The three species of the genus Edessa analyzed have different chromosome complements. Whereas the karyotype of E. meditabunda has the ancestral chromosome number of $2 \mathrm{n}=14$, that of $E$. collaris has been reduced by fusion to $2 \mathrm{n}=12$ and that of $E$. affinis increased by fission to $2 n=16$. Rebagliati \& Mola (2010) studied three species of the genus Acledra and found a reduced complement $(\mathrm{n}=5+\mathrm{XY})$ in A. bonariensis consisting of a markedly large pair of chromosomes, and three medium-sized and a smaller pair, which it shares with $A$. kinbergii and $A$. modesta. This chromosome complement may have originated from the fusion of two large nonhomologous autosomes, which characterized the ancestral karyotype of the genus. In the species Dichelops melacanthus, it is assumed that an autosomal fusion occurred because of the presence of a large autosome, but studies on other species of the same genus are necessary to confirm this hypothesis.

There is little information on the evolution of these chromosomes in the literature, because it is difficult to detect structural variation due to lack of a morphologically differentiated centromere and of longitudinal chromosome differentiation. For these reasons chromosomal rearrangements, such as inversions and reciprocal translocations, are rarely reported in these organisms, which make it difficult to draw any conclusions. Advanced techniques together with the classical cytogenetic methods used in this study, are likely to increase the understanding of the evolution of this group, for example, which family, number of lobes and sex chromosome system is ancestorial?

ACKNOWLEDGMENTS. Special thanks go to J. Grazia of the Department of Zoology of Universidade Federal do Rio Grande do Sul and A. Barcellos of the Museu de Ciências Naturais of Porto Alegre, Brazil, who helped with the identification of specimens. This research was funded by the Foundation for the Development of Sao Paulo State University (FUNDUNESP), Foundation for Research Support of the State of São Paulo (FAPESP) and National Counsel of Technological and Scientific Development CNPq.

\section{REFERENCES}

BowEN R.H. 1922: Notes on the occurrence of abnormal mitosis in spermatogenesis. Biol. Bull. 43: 184-203.

Bressa M.J., Fumagalli E., Ituarte S., Frassa M.V. \& LarraMENDY M.L. 2002: Meiotic studies in Dysdercus Guérin Méneville 1831 (Heteroptera: Pyrrhocoridae). II. Evidence on variations of the diffuse stage between wild and laboratoryinbred populations of Dysdercus chaquency Freiberg, 1948. Hereditas 137: 125-131.

Bressa M.J., Papeschi A.G., VítKová M., Kubícková S., Fuková I., Pigozzi M.I. \& Marec F. 2009: Sex chromosome evolution in cotton stainers of the genus Dysdercus (Heteroptera: Pyrrhocoridae). Cytogenet. Genome Res. 125: 292-305.

BucK R.C. 1967: Mitosis and meiosis in Rhodnius prolixus: the fine structure of the spindle and diffuse kinetochore. J. Ultrastruct. Res. 18: 489-501.

Castanhole M.M.U., Pereira L.L.V., Souza H.V., Bicudo H.E.M.C., Costa L.A.A. \& Itoyama M.M. 2008: Heteropicnotic chromatin and nucleolar activity in meiosis and spermiogenesis of Limnogonus aduncus (Heteroptera, Gerridae): a stained nucleolar organizing region that can serve as a model for studying chromosome behavior. Genet. Mol. Res. 7: 1398-1407.

Comings D.E. \& OKadA T.A. 1972: Holocentric chromosomes in Oncopeltus: kinetochore plates are present in mitosis but absent in meiosis. Chromosoma 37: 177-192.

Costa L.C., Azeredo-Oliveira M.T.V. \& Tartarotti E. 2008: Spermatogenesis and nucleolar activity in Triatoma klugi (Triatomine, Heteroptera). Genet. Mol. Biol. 31: 438-444.

González-Garcia J.M., Antonio C., Suja J.A. \& Rufas J.S. 1996: Meiosis in holocentric chromosomes: kinetic activity is randomly restricted to the chromatid ends of sex univalents in Graphosoma italicum (Heteroptera). Chromos. Res. 4: 124-132.

Grozeva S.M. \& KuzNetsova V.G. 1992: The reproductive system of some bug families (Heteroptera, Pentatomomorpha). In Bennetova B., Gelbic I. \& Soldan T. (eds): Advances in Reproduction of Insect Reproduction. Institute of Entomology, Czech Academy of Science, Ceske Budejovice, pp. 97-102.

Grozeva S. \& Nokkala S. 1996: Chromosomes and their behaviour in two families of the primitive infraorder Dipsocoromorpha (Heteroptera). Hereditas 125: 31-36.

Hughes-Schrader S. \& Schrader F. 1961: The Kinetochore of the Hemiptera. Chromosoma 12: 327-350.

JACOBS D.H. 2004: The evolution of a neo- $\mathrm{XY}_{1} \mathrm{Y}_{2}$ sex chromosome system by autosome sex chromosome fusion in Dundocoris nodulicarius Jacobs (Heteroptera: Aradidae: Carventinae). Chromos. Res. 12: 175-191.

JoHN B. \& KING M. 1985: Pseudoterminalization, terminalization and non-chiasmate modes of terminal association. Chromosoma 92: 89-99.

Jones G.H. 1987: Chiasmata. In Monees P.B. (ed.): Meiosis. Academic Press, Orlando, pp. 213-244.

ManNa G.K. 1984: Chromosomes in evolution in Heteroptera. In Sharma A.K. (ed.): Chromosomes in Evolution of Eukaryotic Groups. CRC Press, Boca Raton, pp. 189-225.

Motzko D. \& Ruthmann A. 1984: Spindle membranes in mitosis and meiosis of the heteropteran insect Dysdercus intermedius. A study of the interrelationship of spindle architecture and the kinetic organization of chromosomes. Eur. J. Cell Biol. 33: 205-216.

Papeschi A.G. \& Bidau C.J. 1985: Chromosome complement and male meiosis in four species of Belostoma Latreille (Heteroptera - Belostomatidae). Rev. Brasil. Genet. VIII 2: 249-261.

PAPeschi A.G. \& BRessa M.J. 2006: Evolutionary cytogenetics in Heteroptera. J. Biol. Res. 5: 3-21.

Rebagliati P.J. \& Mola L.M. 2010: Meiotic behavior and karyotypic variation in Acledra (Pentatomidae, Heteroptera). Genet. Mol. Res. 9: 739-749.

Rebagliati P.J., Mola L.M., Papeschi A.G. \& Grazia J. 2005: Cytogenetics studies in Pentatomidae (Heteroptera): A review. J. Zool. Syst. Evol. Res. 43: 199-213.

Rufas J.S. \& GimÉNez-Martín G. 1986: Ultrastructure of the kinetochore in Graphosoma italicum (Hemiptera: Heteroptera). Protoplasma 32: 142-148.

Schaefer C.W. \& Panizzi A.R. 2000: Heteroptera of Economic Importance. CRC Press, Boca Raton, pp. 421-474.

SCHRAder F. 1935: Notes on the mitotic behaviour of long chromosomes. Cytologia (Tokyo) 6: 422-430.

SCHRADER F. 1940: The formation of tetrads and the meiotic mitoses in the male of Rhytidolomia senilis Say (Hemiptera, Heteroptera). J. Morphol. 67: 123-141.

SCHRADER F. 1945a: Regular occurrence of heteroploidy in a group of Pentatomidae (Hemiptera). Biol. Bull. 88: 63-70. 
Schrader F. 1945b: The cytology of regular heteroploidy in the genus Loxa (Pentatomidae - Hemiptera). J. Morphol. 76: $157-177$.

Schrader F. 1946a: The elimination of chromosomes in the meiotic divisions of Brachystethus rubromaculatus Dallas. Biol. Bull. 90: 19-31.

SCHRADER F. 1946b: Autosomal elimination and preferential segregation in the harlequin lobe of certain Discocephalini (Hemiptera). Biol. Bull. 90: 264-290.

SCHRADER F. 1960a: Cytological and evolutionary implications of aberrant chromosome behavior in the harlequin lobe of some Pentatomidae (Heteroptera). Chromosoma 11: 103-128.

SCHRADER F. 1960b: Evolutionary aspects of aberrant meiosis in some Pentatomidae (Heteroptera). Evolution 14: 498-508.

Schun T.T. \& Slater J.A. 1995: The Bugs of the World (Hemiptera: Heteroptera) Classification and Natural History, Cornell University Press, Ithaca, New York, 336 pp.

Solari A. \& Agopian S. 1987: Recombination nodules, synaptonemal complexes and heterochromatin in the hemipteran Triatoma infestans. Microsc. Electron. Biol. Celul. 11: 179-195.

Souza H.V. \& Iтоунам M.M. 2010: Comparative study of spermatogenesis and nucleolar behavior in testicular lobes of Euschistus heros (Heteroptera: Pentatomidae). Psyche 2010: doi:10.1155/2010/428673.

Souza H.V., Arakaki R.L.M., Dias L.N., MuraKami-Lima A.S., Costa L.A.A., Bicudo H.E.M.C. \& Itoyama M.M 2007a: Cytogenetical aspects of testicular cells in economically important species of Coreidae family (Heteroptera). Cytologia 72: $49-56$
Souza H.V., Bicudo H.E.M.C. \& Itoyama M.M. 2007b: Study of chromosomal and nucleolar aspects in testes of Nysius californicus (Heteroptera: Lygaeidae). Genet. Mol. Res. 6: 33-40.

Souza H.V., Bicudo H.E.M.C., Costa L.A.A. \& Itoyama M.M. 2007c: A study of meiosis and spermatogenesis in different testicular lobes of Antiteuchus tripterus (Heteroptera: Pentatomidae). Eur. J. Entomol. 104: 353-362.

Souza H.V., Castanhole M.M.U., Bicudo H.E.M.C., Costa L.A.A. \& Iтoyama M.M. 2008: Morphological patterns of the heteropycnotic chromatin and nucleolar material in meiosis and spermiogenesis of Mormidea v-luteum, Oebalus poecilus and Oebalus ypsilongriseus (Heteroptera, Pentatomidae). Genet. Mol. Biol. 31: 686-691.

Souza H.V., Souza F.B., Maruyama S.R.C., Castanhole M.M.U. \& Itoyama M.M. 2009: Meiosis, spermatogenesis and nucleolar behavior in the seminiferous tubules of Alydidae, Coreidae and Rhopalidae (Heteroptera) species. Genet. Mol. Res. 8: 1383-1396.

Ueshima N. 1979: Animal Cytogenetics, Insecta 6, Hemiptera: Heteroptera. Gebruder Borntraeger, Berlin, Stuttgart, $117 \mathrm{pp}$.

Ueshima N. \& Ashlock P.D. 1980: Cytotaxonomy of the Lygaeidae (Heteroptera). Univ. Kans. Sci. Bull. 51: 717-801.

Wolf K.W. 1996: Acetylation of $\alpha$-tubulin in male meiotic spindles of Pyrrhocoris apterus, an insect with holocentric chromosomes. Protoplasma 191: 148-157.

Received November 18, 2010; revised and accepted February 28, 2011 